Analisis Hasil Belajar Matematika dan Hasil Try-Out Ujian Nasional Matematika ...

Available online at website:

http://e-journal.adpgmiindonesia.com/index.php/jmie

JMIE: Journal of Madrasah Ibtidaiyah Education, 5(2), 2021, 214-226

\title{
ANALISIS HASIL BELAJAR MATEMATIKA DAN HASIL TRY-OUT UJIAN NASIONAL MATEMATIKA PESERTA DIDIK MADRASAH IBTIDAIYAH
}

\author{
Nur Fitriani Zainal1), Nurhayati Sahibe'2), Satriani ${ }^{3)}$ \\ Institut Agama Islam Negeri (IAIN) Manado \\ E-mail: nur.zainal@iain-manado.ac.id1),nur.sahibe@iain-manado.ac.id, \\ satrianiqwee@iain-manado.ac.id ${ }^{3}$ )
}

Submit: 16 Februari 2021, Revisi: 10 Oktober 2021, Approve: 8 November 2021

\begin{abstract}
This study aims to describe the learning outcomes of Mathematics, the results of the Mathematics National Examination try-out, and test the significance of the differences between the Mathematic learning outcomes and the Mathematics National Examination tryout results. The research was conducted through a quantitative approach with a research population of 92 students of 6th-grade of MIN in Manado city. Research data were collected using documentation techniques and test techniques. Documentation of learning outcomes in the form of 5th-grade report cards for even semester Mathematics 2018/2019 and a test in the form of the Try-out of Mathematics National Examination (UN) which was carried out twice. The collected data were then analyzed descriptively and inferentially using the Wilcoxon test. The Wilcoxon test was used because the data on Mathematics learning outcomes were not normally distributed. From the results of the analysis, it has known that: 1) The category of students' mathematics learning outcomes is in the range of Very Good, Good and Sufficient predicates and if averaged, it is in the Enough predicate, 2) The Scores of the try-out of mathematic National Examination are in the less category and 3) there is a significant difference between the results of learning Mathematics and the results of the Try-Out of Mathematics National Examination (UN) of students. The results of this study can be used as reflective material for teachers in maximizing students' basic Mathematics skills which will have an impact on learning Mathematics at the next level and in preparing SD/MI students to face National and International assessments.
\end{abstract}

Keywords: Mathematics Learning Outcomes, the Mathematics National Examination Try-out results.

Pengutipan: Nur Fitriani Zainal, dkk. (2021). Analisis Hasil Belajar Matematika dan Hasil TryOut Ujian Nasional Matematika Peserta Didik Madrasah Ibtidaiyah. JMIE: Journal of Madrasah Ibtidaiyah Education, 5(2), 2021, 213-226. jmie.v5i2.261.

Permalink/DOI: http://dx.doi.org/10.32934/jmie.v5i2.261 
Analisis Hasil Belajar Matematika dan Hasil Try-Out Ujian Nasional Matematika ...

\section{PENDAHULUAN}

Pada tingkat SD/MI, salah satu mata pelajaran yang dinilai oleh pendidik melalui penilaian akhir dan dinilai oleh pemerintah melalui Ujian Nasional adalah Matematika. Lingkup materi Matematika tingkat Sekolah Dasar/Madrasah Ibtidaiyah, yaitu: 1) Bilangan, 2) Geometri dan Pengukuran, serta 3) Statistika dan Peluang (Kemendikbud, 2016).

Peserta didik pada jenjang SD/MI mampu memperoleh nilai Kriteria Ketuntasan Minimal (KKM) Matematika bahkan di atas nilai KKM Matematika berdasar nilai rapor. Dari fakta tersebut, maka dapat diasumsikan bahwa peserta didik menguasai pengetahuan Matematika, terampil secara matematis dan memperoleh hasil belajar Matematika yang tuntas.

Di sisi lain, hasil belajar Matematika yang dievaluasi pada tingkat Nasional dan Internasional teridentifikasi mengkhawatirkan. Pada tingkat Nasional terlihat dari hasil UN SMP/MTs di berbagai daerah, salah satunya di kota Manado yang dalam 3 tahun terakhir, nilai rerata ujian Nasional Matematika pada tingkat kota berada di bawah nilai rerata Ujian Nasional tingkat Provinsi dan Nasional (Puspendik, 2019) dan pada tingkat Internasional tampak dari hasil capaian Indeks Programme for International Student Assessment (PISA) Indonesia pada Tahun 2000 sampai dengan Tahun 2015 khususnya pada materi Matematika dengan skor rerata Internasional sebesar 500, yaitu: 1. Pada tahun 2000, skor rerata Indonesia adalah 367, sehingga menduduki urutan ke-39 dari 41 Negara; 2. Pada tahun 2003 skor rerata Indonesia adalah 360, sehingga menduduki peringkat ke-38 dari 40 Negara; 3. Pada Tahun 2006, skor rerata Indonesia adalah 396, sehingga menduduki peringkat ke-50 dari 56 Negara; 4. Pada Tahun 2009, skor rerata Indonesia adalah 371, sehingga menduduki urutan ke-61 dari 65 Negara; 5. Pada Tahun 2012, skor rerata Indonesia adalah 375, sehingga menduduki urutan ke-64 dari 65 negara; 6. Pada Tahun 2015, skor rerata Indonesia adalah 386, sehingga menduduki urutan ke-63 dari 69 Negara (Pratiwi, 2019) dan 7. Pada Tahun 2018, skor rerata Indonesia adalah 379 dimana 110 poin dibawah rerata OECD sebesar 489 (Avvisati et al., 2018).

Di samping itu, berdasarkan hasil TIMSS 2011, khususnya pada International Mathematics Achievement 8th grade, Indonesia pada posisi ke-38 dari 42 Negara dengan nilai 386, menurun sebanyak 11 poin dari tahun 2007 (Mullis et al., 2012) dan pada laporan TIMSS 2015, khususnya pada International Mathematics Achievement 4th grade, Indonesia pada posisi ke-44 dari 49 Negara dengan nilai 397 (Mullis et al., 2016).

Temuan menarik dari beberapa penelitian pendidikan menyatakan pula bahwa: 1 . terdapat kesenjangan antara kecakapan siswa dan ukuran baku yang ditetapkan pada kurikulum; 2. rata-rata kemampuan berhitung siswa kelas VII di tahun 2014 sepadan kemampuan berhitung siswa kelas IV di tahun 2000 (Beatty et al., 2021); 3. terdapat hubungan signifikan antara kecakapan aritmatika dan literasi Matematika sehingga siswa yang mempunyai keterampilan tinggi dalam operasi hitung memungkinkan mempunyai keterampilan literasi Matematika tinggi (Y1lmazer \& Masal, 2014); 4. pada pembelajaran Matematika, penilaian memiliki peranan penting 
dalam keberlanjutan proses transfer pengetahuan, sebab dari hasil penilaian tersebut, maka diperoleh data tentang tingkat kemampuan peserta didik dan informasi tentang konsep tertentu yang belum dipahami peserta didik (Retnawati et al., 2017) dan 5. Penilaian pendidik di Sekolah Dasar tidak dapat difungsikan menjadi objek pemetaan mutu pembelajaran karena tes yang diujikan tidak standar dan memiliki kualitas yang berbeda (Pakpahan, 2015).

Berdasarkan ketuntasan hasil belajar Matematika peserta didik pada jenjang SD/MI, ironi hasil evaluasi Matematika di tingkat Nasional, temuan penelitian tentang kesenjangan kemampuan peserta didik dengan standar yang ditetapkan kurikulum serta kedudukan hasil penilaian pendidik sebagai jaminan mutu pembelajaran tingkat sekolah, maka peneliti tertarik melaksanakan penelitian yang bertujuan: 1. mendeskripsikan hasil belajar Matematika, 2. mendeskripsikan hasil Try-Out UN Matematika sebagai hasil simulasi evaluasi tingkat Nasional dan 3. menguji signifikansi perbedaan antara hasil belajar Matematika dan hasil Try-Out UN Matematika, khususnya di Manado pada tingkat Madrasah Ibtidaiyah Negeri. Simpulan penelitian ini diharapkan menjadi bahan refleksi guru dalam memaksimalkan kemampuan dasar Matematika peserta didik yang bisa berimplikasi pada pembelajaran matematika di jenjang berikutnya dan dalam mempersiapkan peserta didik SD/MI menghadapi penilaian Nasional dan Internasional.

\section{METODE}

Penelitian ini menggunakan pendekatan kuantitatif untuk mendeskripsikan hasil belajar Matematika dan hasil Try-Out UN Matematika, serta menguji signifikansi perbedaan antara hasil belajar Matematika dan hasil Try-Out UN Matematika peserta didik MIN di Manado. Variabel penelitian adalah hasil belajar Matematika dan nilai Try-Out UN Matematika, sehingga objek utama penelitian berupa data hasil belajar Matematika dan nilai Try-Out UN Matematika. Penelitian dilaksanakan pada bulan Juli hingga Oktober Tahun 2019. Populasi penelitian ialah peserta didik Kelas VI Madrasah Ibtidaiyah Negeri di Manado yakni sebanyak 92 peserta didik. Sampel penelitian ialah peserta didik kelas VI MIN di Manado, dimana: 1. Pada Try-Out I Ujian Nasional Matematika diikuti sebanyak 87 peserta didik, dan 2. Pada Try-Out II Ujian Nasional Matematika diikuti sebanyak 84 peserta didik.

Dalam mengumpulkan data digunakan teknik dokumentasi dan teknik tes. Dokumentasi berupa data hasil belajar Matematika (penilaian aspek kognitif) kelas V pada rapor semester genap tahun akademik 2018/2019 sampel penelitian. Tes dilakukan untuk mengetahui nilai Try-Out Ujian Nasional Matematika. Instrumen tes berupa Soal Ujian Nasional Matematika SD/MI. Pelaksanaan Try-Out Ujian Nasional Matematika dilakukan sebanyak dua kali.

Pada tahap analisis data, data hasil belajar Matematika dan nilai Try-Out UN Matematika dianalisis secara deskriptif dan inferensial. Analisis deskriptif berfungsi untuk mendeskripsikan kategori hasil belajar peserta didik dan nilai Try-Out UN Matematika. Analisis Inferensial 
digunakan untuk menguji hipotesis penelitian melalui prosedur uji Normalitas dan uji Wilcoxon. Uji Wilcoxon digunakan karena data nilai hasil belajar Matematika tidak berdistribusi normal sedang data nilai try-out Ujian Nasional Matematika berdistribusi normal. Hal ini, sesuai dengan pendapat "When the samples are dependent, as they would be in a before-and-after test using the same subjects, the Wilcoxon signed-rank test can be used in place of the t test for dependent samples. Again, this does not require the condition of normality" (Bluman, 2012). Dari pendapat tersebut, diketahui bahwa Uji Wilcoxon Signed-Rank dapat digunakan sebagai pengganti uji-t, jika sampel terikat dan tidak berdistribusi normal. Analisis data dilakukan berbantuan aplikasi SPSS.

\section{HASIL PENELITIAN DAN PEMBAHASAN}

\section{Deskripsi Hasil Belajar Matematika Peserta Didik MIN di Kota Manado}

Di bawah ini merupakan hasil belajar peserta didik pada Madrasah Ibtidaiyah Negeri (MIN) di Manado.

Tabel 1. Hasil Belajar Matematika Peserta Didik MIN di Manado

\begin{tabular}{lccc}
\hline Statistics & $\begin{array}{c}\text { Hasil Belajar } \\
\text { Populasi }\end{array}$ & $\begin{array}{c}\text { Hasil Belajar } \\
\text { Sampel Try-out I }\end{array}$ & $\begin{array}{c}\text { Hasil Belajar } \\
\text { Sampel Try-out II }\end{array}$ \\
\hline N & 92 & 87 & 84 \\
Mean & 82.10 & 82.22 & 82.26 \\
Std. Deviation & 5.15 & 5.21 & 5.19 \\
Minimum & 75 & 75 & 75 \\
Maximum & 99 & 99 & 99 \\
\hline
\end{tabular}

Berdasarkan Hasil Desciptive Statistics pada Tabel 1 menunjukkan bahwa nilai minimum hasil belajar Matematika adalah 75, nilai maksimum hasil belajar Matematika adalah 99, rerata nilai hasil belajar Matematika pada populasi ialah 82,10 dengan jumlah peserta didik 92 orang, rerata nilai hasil belajar Matematika sampel Try-Out I ialah 82,22 dengan jumlah peserta didik 87 orang dan rerata nilai hasil belajar Matematika sampel Try-Out II ialah 82,26 dengan jumlah peserta didik 84 orang.

Deskripsi Hasil Try-Out Ujian Nasional Matematika Peserta Didik MIN di Kota Manado

Tabel 2. Hasil Try-Out UN Matematika Peserta Didik MIN di Manado

\begin{tabular}{lcc}
\hline Statistics & Try-Out I & Try-Out II \\
\hline $\mathrm{N}$ & 87 & 84 \\
Mean & 24.99 & 26.67 \\
\hline
\end{tabular}




$\begin{array}{lcc}\text { Std. Deviation } & 7.688 & 8.69 \\ \text { Minimum } & 8 & 7 \\ \text { Maximum } & 47 & 43\end{array}$

Berdasarkan Hasil Descriptive Statistics pada Tabel 2 diketahui bahwa nilai minimum hasil Try-Out I Ujian Nasional Matematika adalah 8, nilai minimum hasil Try-Out II Ujian Nasional Matematika adalah 7, nilai maksimum hasil Try-Out I Ujian Nasional Matematika adalah 47, nilai maksimum hasil Try-Out II Ujian Nasional Matematika adalah 43, rerata hasil Try-Out I Ujian Nasional Matematika adalah 24,99 dengan jumlah peserta didik 87 orang dan rata-rata hasil TryOut II Ujian Nasional Matematika adalah 26,67 dengan jumlah peserta didik 84 orang.

\section{Komparasi Nilai Hasil Belajar Matematika dan Nilai Try-Out UN Matematika Peserta Didik MIN di Kota Manado}

\section{a. Komparasi Nilai Hasil Belajar Matematika dan Nilai Try-Out I UN Matematika peserta didik MIN di Kota Manado}

Hasil uji normalitas, Ranks Uji Wilcoxon dan Uji Wilcoxon disajikan berikut:

Tabel 3. Hasil Uji Normalitas Nilai Hasil Belajar dan Nilai Try-Out I UN Matematika Peserta Didik MIN di Manado

\begin{tabular}{llcc}
\hline & & Hasil Belajar & Hasil Try-Out I \\
\hline $\mathrm{N}$ & & 87 & 87 \\
Normal Parameters $^{\mathrm{a}}$ & Mean & 82.22 & 24.99 \\
& Std. Deviation & 5.206 & 7.688 \\
\multirow{2}{*}{ Most Extreme Differences } & Absolute & .183 & .108 \\
& Positive & .183 & .108 \\
& Negative & -.083 & -.097 \\
Kolmogorov-Smirnov Z & & 1.711 & 1.005 \\
Asymp. Sig. (2-tailed) & & .006 & .264 \\
\hline
\end{tabular}

a. Test distribution is Normal

Hasil Uji Normalitas dengan One-Sample Kolmogorov-Smirnov Test pada Tabel 3 memperlihatkan bahwa hasil belajar Matematika peserta didik untuk sampel Try-Out I tidak berdistribusi normal dengan Asymp.Sig.(2-tailed): 0,006 (<0,05) sedang Nilai TryOut I Ujian Nasional Matematika peserta didik berdistribusi normal dengan Asymp.Sig.(2-tailed): 0,264 (>0,05). 
Tabel 4. Ranks Uji Wilcoxon Hasil Belajar Matematika Sampel Try-Out I dan Nilai Try-Out I Peserta Didik MIN di Manado

\begin{tabular}{ccccc}
\hline & N & $\begin{array}{r}\text { Mean } \\
\text { Ranks }\end{array}$ & Sum Of Ranks \\
\hline Try-Out I - Hasil Belajar & Negative Rank & $87^{\mathrm{a}}$ & 44.00 & 3828.00 \\
& Positive Rank & $0^{\mathrm{b}}$ & .00 & .00 \\
& Ties & $0^{\mathrm{c}}$ & & \\
& Total & 87 &
\end{tabular}
a. Try-Out I < Hasil Belajar
b. Try-Out I $>$ Hasil Belajar
c. Try-Out I $=$ Hasil Belajar

Pada Tabel 4, Ranks Uji Wilcoxon menunjukkan bahwa terdapat sebanyak 87 data penurunan dari nilai hasil belajar ke nilai Try-Out I Ujian Nasional Matematika atau terdapat sebanyak 87 data nilai Try-Out I Ujian Nasional Matematika yang lebih kecil dari nilai hasil belajar Matematika peserta didik sampel Try-Out I.

Tabel 5. Hasil Uji Wilcoxon Nilai Hasil Belajar Matematika Sampel Try-Out I dan Nilai Try-Out I UN Matematika Peserta Didik MIN di Manado

\section{Try-Out I-Hasil Belajar}

\begin{tabular}{lc}
\hline $\mathrm{Z}$ & $-8.103^{\mathrm{a}}$ \\
Asymp. Sig. (2-tailed) & .000 \\
\hline
\end{tabular}

a. Based on positive Ranks

b. Wilcoxon Signed Rank Test

Pada Tabel 5, Hasil Uji Wilcoxon menunjukkan bahwa nilai Z bernilai -8,103 dengan Asymp.Sig.(2-tailed): 0,000 (<0,05) sehingga disimpulkan ada perbedaan yang signifikan antara hasil belajar Matematika peserta didik sampel Try-Out I dengan hasil Try-Out I Ujian Nasional Matematika peserta didik. 


\section{b. Komparasi Nilai Hasil Belajar Matematika dan Nilai Try-Out II UN Matematika Peserta Didik MIN di Kota Manado}

Hasil uji normalitas, Ranks Uji Wilcoxon dan Uji Wilcoxon disajikan berikut:

Tabe1 6. Hasil Uji Normalitas Nilai Hasil Belajar dan Nilai Try-Out II UN Matematika peserta didik MIN di Manado

\begin{tabular}{llcc}
\hline & & Hasil Belajar & Hasil Try-Out II \\
\hline N & & 84 & 84 \\
Normal Parameters & & 82.26 & 26.67 \\
& Mean & 5.191 & 8.692 \\
Most Extreme Differences & Std. Deviation & .175 & .116 \\
& Absolute & .175 & .116 \\
& Positive & -.081 & -.085 \\
Kolmogorov-Smirnov Z & Negative & 1.603 & 1.061 \\
Asymp. Sig. (2-tailed) & & .012 & .210 \\
\hline
\end{tabular}

a. Test distribution is Normal

Hasil Uji Normalitas dengan One-Sample Kolmogorov-Smirnov Test pada Tabel 6 memperlihatkan bahwa hasil belajar Matematika peserta didik untuk sampel Try-Out II tidak berdistribusi normal dengan Asymp.Sig.(2-tailed): 0,012 (<0,05) sedang Nilai TryOut II Ujian Nasional Matematika peserta didik berdistribusi normal dengan Asymp.Sig.(2-tailed): 0,210 (>0,05).

Tabel 7. Ranks Uji Wilcoxon Hasil Belajar Matematika Sampel Try-Out II dan Nilai Try-Out II Peserta Didik MIN di Manado

\begin{tabular}{ccccc}
\hline & $\mathbf{N}$ & $\begin{array}{c}\text { Mean } \\
\text { Ranks }\end{array}$ & Sum Of Ranks \\
\hline Try-Out II - Hasil Belajar & Negative Rank & $84^{\mathrm{a}}$ & 42.50 & 3570.00 \\
& Positive Rank & $0^{\mathrm{b}}$ & .00 & .00 \\
& Ties & $0^{\mathrm{c}}$ & & \\
& Total & 84 & &
\end{tabular}

a. Try-Out II < Hasil Belajar

b. Try-Out II $>$ Hasil Belajar

c. Try-Out II = Hasil Belajar 
Pada Tabel 7, Ranks Uji Wilcoxon memperlihatkan bahwa terdapat sebanyak 84 data penurunan dari nilai hasil belajar ke nilai Try-Out II Ujian Nasional Matematika atau terdapat sebanyak 84 data nilai Try-out II Ujian Nasional Matematika yang lebih kecil dari nilai hasil belajar Matematika peserta didik sampel Try-Out II.

Tabe1 8. Hasil Uji Wilcoxon Nilai Hasil Belajar Matematika Sampel Try-Out II dan Nilai Try-Out II UN Matematika Peserta Didik MIN di Manado

\begin{tabular}{lr}
\hline & Try-Out II - Hasil Belajar \\
\hline $\mathrm{Z}$ & $-7.963^{\mathrm{a}}$ \\
Asymp. Sig. (2-tailed) & .000 \\
\hline $\begin{array}{l}\text { a. Based on positive Ranks } \\
\text { b. Wilcoxon Signed Rank Test }\end{array}$
\end{tabular}

Pada Tabel 8, Hasil Uji Wilcoxon menunjukkan bahwa nilai Z bernilai -7,963 dengan Asymp.Sig.(2-tailed): 0,000 < (0,05) sehingga dapat disimpulkan ada perbedaan yang signifikan antara hasil belajar Matematika peserta didik sampel Try-Out II dengan hasil Try-Out II Ujian Nasional Matematika peserta didik.

\section{PEMBAHASAN}

Bukti signifikansi perbedaan antara hasil belajar Matematika dengan hasil Try-Out UN Matematika peserta didik dapat terlihat pada kesenjangan antara descriptive statistics data hasil belajar Matematika dan descriptive statistics data hasil Try-Out UN Matematika peserta didik MIN di Manado. Hasil descriptive statistics data hasil belajar Matematika peserta didik MIN di Manado yang jika dibandingkan dengan tabel rentang predikat Kriteria Ketuntasan Minimal $(\mathrm{KKM})=$ 75 pada dokumen Panduan Penilaian untuk Sekolah (Direktorat Pembinaan Sekolah Dasar, 2018) menunjuk pada rentang predikat Sangat Baik $(92<\mathrm{B} \leq 100)$, Baik $(83<\mathrm{B} \leq 92)$ dan Cukup $(75<\mathrm{B} \leq 83)$ serta jika dirata-ratakan maka berada pada predikat Cukup. Di sisi lain, hasil descriptive statistics data hasil Try-Out UN Matematika peserta didik MIN di Manado yang jika dibandingkan dengan rentang pencapaian kompetensi lulusan dalam Ujian Nasional pada buku saku UN (BSNP, 2019) menunjukkan bahwa nilai Try-Out I dan II Ujian Nasional Matematika peserta didik berada pada kriteria kurang $(0 \leq \mathrm{x} \leq 55)$.

Perolehan nilai Try-Out UN Matematika tingkat MIN di Manado yang berada pada kriteria kurang bersinergi dengan simpulan penelitian yang menyatakan bahwa pada tingkat Sekolah Dasar, sebanyak 88,57 \% peserta didik terkendala mengerjakan soal Matematika Indonesian Nasional Assessment Programme (INAP) (Retnawati et al., 2011). 
Kurangnya hasil Try-Out UN Matematika tingkat MIN di Manado, mengindikasikan kepelikan peserta didik dalam belajar Matematika. Secara umum, fakta kepelikan peserta didik SD/MI dalam belajar Matematika dapat dilihat dari berbagai hasil penelitian diagnostik kesulitan belajar Matematika pada tingkat Sekolah Dasar. Berdasarkan abstraksi hasil penelitian, maka beberapa pemicu kesulitan belajar Matematika disebabkan oleh kemampuan operasi hitung yang lemah atau tidak melakukan operasi hitung dengan benar (Nursalam, 2016; Wulansari \& Kumaidi, 2015), tidak paham terhadap aturan bilangan berpangkat, tidak mengimplementasikan rumus atau sifat bangun datar \& ruang, serta tidak memahami materi rerata, modus dan median dari data berbentuk kumpulan atau tabel (Wulansari \& Kumaidi, 2015).

Oleh karena itu, secara umum teridentifikasi bahwa kesulitan belajar Matematika pada peserta didik SD/MI beraneka ragam, yaitu kesulitan: pemahaman konsep, keterampilan Matematika dan pemecahan masalah (Darjiani et al., 2015; Widyasari et al., 2015). Di samping itu, secara teoretis kesulitan peserta didik dalam belajar Matematika disebabkan oleh faktor internal, yaitu: sikap siswa terhadap Matematika (Sumantri \& Puspita, 2014), minat, motivasi dan intelegensi serta faktor eksternal, yaitu: guru dan buku siswa (Widyasari et al., 2015), lingkungan sosial dan kurikulum (Darjiani et al., 2015) serta lingkungan belajar (Sumantri \& Puspita, 2014).

Kontinuitas dampak kesulitan belajar Matematika di kota Manado tampak dari laporan hasil Ujian Nasional SMP/MTs tiga tahun terakhir (Puspendik, 2019), diketahui bahwa: Pada tahun 2017, rerata nilai Ujian Nasional Matematika sebesar 36,55 atau berada 19,75 poin di bawah dari rerata nilai Ujian Nasional Matematika provinsi atau 13,76 poin dari rerata Ujian Nasional Matematika secara Nasional. Pada tahun 2018, rerata nilai Ujian Nasional Matematika sebesar 35,23 atau berada 6,21 poin di bawah dari rerata nilai Ujian Nasional Matematika provinsi atau 8,11 poin dari rerata Ujian Nasional Matematika secara Nasional. Pada tahun 2019, rerata nilai Ujian Nasional Matematika sebesar 38,77 atau berada 2,07 poin di bawah dari rerata nilai Ujian Nasional Matematika provinsi atau 6,75 poin dari rerata Ujian Nasional Matematika secara Nasional. Pada tingkat SMA/MA Program Studi IPA tahun 2019 (Puspendik, 2019) pun diketahui bahwa rerata nilai Ujian Nasional Matematika sebesar 33,35 atau berada 0,32 di atas dari rerata nilai Ujian Nasional Matematika provinsi atau 5,25 poin di bawah dari rerata ujian Nasional Matematika secara Nasional.

Kesulitan belajar Matematika peserta didik dapat diatasi melalui konsistensi guru dalam menerapkan kombinasi model pembelajaran, strategi, pendekatan, metode, penggunaan media dan penilaian yang bervariasi dan menarik. Bukti penanganan ini tertulis dalam beberapa abstrak penelitian yang dapat diadaptasi dan dikembangkan, seperti: a) Implementasi model pembelajaran kooperatif tipe Numbered Head Together berbantuan Media Konkret mampu memaksimalkan hasil belajar (Susila et al., 2015), b) Pengaruh positif desain pembelajaran melalui pendekatan RME menggunakan media pembelajaran permainan ular tangga terhadap 
pemahaman siswa pada materi penjumlahan dan pengurangan bilangan dua angka (Fauzi et al., 2021), c) Pembelajaran Matematika melalui field trip efektif dalam memaksimalkan kemampuan literasi matematis siswa pada materi pembulatan dan skala (Khotimah et al., 2019), d) Pemanfaatan media komik mampu mengoptimalkan kemampuan koneksi matematis siswa SD (Musyarrofah et al., 2019), e) Penerapan Strategi Pembelajaran REACT mampu mengoptimalkan kompetensi berpikir kritis matematis pada materi bangun datar segiempat (Hidayat et al., 2020), f) Implementasi metode penemuan terbimbing mampu mengoptimalkan kompetensi pemahaman konsep dan berpikir kritis siswa (Karim, 2011), g) Pencapaian nilai tinggi dengan penerapan asesmen autentik matematika khususnya aspek kognitif dan keterampilan untuk siswa SD kelas IV (Chusnia et al., 2017) dan h) Dalam meningkatkan kemampuan pemecahan masalah siswa, maka guru dituntut untuk memperhatikan aspek pembelajaran berupa perencanaan, proses pembelajaran, penilaian dan pemilihan media atau alat peraga dalam pembelajaran (Lidnillah, 2008).

\section{KESIMPULAN}

Kategori hasil belajar Matematika berdasarkan nilai rapor peserta didik Madrasah Ibtidaiyah Negeri (MIN) di kota Manado dengan Kriteria Ketuntasan Minimal (KKM) sebesar 75 berada pada rentang predikat Sangat Baik, Baik dan Cukup serta jika dirata-ratakan maka berada pada predikat Cukup. Hal tersebut, berbanding terbalik dengan nilai Try-Out Ujian Nasional Matematika peserta didik Madrasah Ibtidaiyah Negeri (MIN) di kota Manado yang berada pada kategori kurang. Kesenjangan antara hasil belajar Matematika dan hasil Try-Out UN Matematika MIN di Manado terbukti dari hasil uji Wilcoxon dimana nilai Asymp.Sig. (2-tailed) < 0,05 .

Potret kesenjangan antara hasil belajar Matematika dan hasil Try-Out UN Matematika peserta didik MIN di Manado dapat dijadikan sebagai bahan refleksi guru Matematika di SD/MI dalam merancang sistem pembelajaran efektif untuk meningkatkan kecakapan Matematika peserta didik SD/MI yang akan berkontribusi pada pembelajaran Matematika di jenjang selanjutnya dan dalam mempersiapkan peserta didik SD/MI menghadapi penilaian bertaraf Nasional dan Internasional serta menjadi bahan pertimbangan pemangku kepentingan dalam menetapkan kebijakan khususnya pada aspek penilaian peserta didik untuk menjamin mutu pendidikan di tingkat SD/MI. 


\section{DAFTAR PUSTAKA}

Avvisati, F., Echazarra, A., Givord, V., \& Schwabe, M. (2018). Indonesia Country Note: Programme for International Student Assessment (PISA) Result from PISA 2018. In OECD. http://www.oecd.org/pisa/ Data

Beatty, A., Berkhout, E., Bima, L., Pradhan, M., \& Suryadarma, D. (2021). Schooling Progress, Learning Reversal: Indonesia's Learning Profiles Between 2000 and 2014. International Journal of Educational Development, 85. https:/ / doi.org/10.1016/j.ijedudev.2021.102436

Bluman, A. G. (2012). Elementary Statistics: A Step by Step Approach (Eighth). McGraw-Hill Companies.

BSNP. (2019). Buku Saku Ujian Nasional 2019. Ujian Nasional, 1-22.

Chusnia, S., Sa'dijah, C., \& Harsiati, T. (2017). Penerapan Instrumen Asesmen Autentik Matematika Aspek Kognitif dan Keterampilan Bagi Siswa Kelas IV SD. Jurnal Pendidikan: Teori, Penelitian, Dan Pengembangan, 2(10), 1437-1442.

Darjiani, N. N. Y., Meter, I. G., \& Negara, I. G. A. O. (2015). Analisis Kesulitan-Kesulitan Belajar Matematika Siswa Kelas V Dalam Implementasi Kurikulum 2013 di SD Piloting Se-Kabupaten Gianyar Tahun Pelajaran 2014 / 2015. E-Journal PGSD Universitas Pendidikan Ganesha, 3(1), 1-11. https:// ejournal.undiksha.ac.id/index.php/JJPGSD/article/view/5070

Direktorat Pembinaan Sekolah Dasar. (2018). Panduan Penilaian untuk Sekolah Dasar (SD). Kementerian Pendidikan dan Kebudayaan.

Fauzi, I., Mauhibah, R., \& Jupri, A. (2021). Learning Designs for the Addition and Subtraction of Two-Digit Numbers based on Realistic Mathematics Education Principles Using Snakes and Ladders Game. Al Ibtida: Jurnal Pendidikan Guru MI, 8(1), 32-49. https://doi.org/10.24235/al.ibtida.snj.v8i1.7741

Hidayat, S., Carlian, Y., \& Rohmah, S. K. (2020). Peningkatan Kemampuan Berpikir Kritis Matematis Peserta Didik dengan Menggunakan Strategi REACT. JMIE (Journal of Madrasah Ibtidaiyah Education), 4(2), 175-196. https://doi.org/10.32934/jmie.v4i2.163

Karim, A. (2011). Penerapan Metode Penemuan Terbimbing dalam Pembelajaran Matematika untuk Meningkatkan Pemahaman Konsep dan Kemampuan Berpikir Kritis Siswa Sekolah Dasar. Jurnal Pendidikan, Edisi Khusus(1), 21-32.

Kemendikbud. (2016). Peraturan Menteri Pendidikan dan Kebudayaan Nomor 21 Tahun 2016 tentang Standar Isi Pendidikan Dasar dan Menengah. https://bsnp-indonesia.org/wpcontent/uploads/2009/06/Permendikbud_Tahun2016_Nomor021_Lampiran.pdf

Khotimah, S. H., Budi, A. S., \& Sumantri, M. S. (2019). Improving Mathematical Literacy Ability of Elementary School Students Through A Field Trip Learning. Al Ibtida: Jurnal Pendidikan Guru MI, 6(2), 219-230. https://doi.org/10.24235/al.ibtida.snj.v6i2.5014 
Lidnillah, D. A. M. (2008). Strategi Pembelajaran Pemecahan Masalah di Sekolah Dasar. Jurnal Pendidikan Dasar, 1-10.

Mullis, I. V. S., Martin, M. O., Foy, P., \& Hooper, M. (2016). TIMSS 2015 International Results in Science Saved. In IEA TIMSS \& PIRLS Internasional Study Centre Lynch School of Education Boston College.

Mullis, I. V. S., Martin, M. O., Pierre Foy, A., \& Alka Arora. (2012). Timss 2011 International Results in Mathematics. In IEA TIMSS \& PIRLS Internasional Study Centre Lynch School of Education Boston College.

Musyarrofah, N., Arifin, F., \& Firdaus, F. M. (2019). Penggunaan Media Komik untuk Meningkatkan Kemampuan Koneksi Matematis Siswa Sekolah Dasar. JMIE Journal of Madrasah Ibtidaiyah Education), 3(2), 219-232. https://doi.org/10.32934/jmie.v3i2.135

Nursalam. (2016). Diagnostik Kesulitan Belajar Matematika: Studi Pada Siswa SD/MI Di Kota Makassar. Lentera Pendidikan: Jurnal Ilmu Tarbiyah Dan Keguruan, 19(1), 1-15. https://doi.org/10.24252/lp.2016v19n1a1

Pakpahan, R. (2015). Ujian Sekolah sebagai Upaya Pemetaan Mutu Sekolah Dasar. Jurnal Pendidikan Dan Kebudayaan, 21(2). https://doi.org/10.24832/jpnk.v21i2.184

Pratiwi, I. (2019). Efek Program PISA terhadap Kurikulum di Indonesia. Jurnal Pendidikan Dan Kebudayaan, 4(1), 51-71. https://doi.org/10.24832/jpnk.v4i1.1157

Puspendik. (2019). Hasil Ujian Nasional. Kementerian Pendidikan Dan Kebudayaan. https://hasilun.puspendik.kemdikbud.go.id/\#2019!smp!capaian_wilayah!17\&99\&999!T $\& 03 \& T \& T \& 1 \& ! 2 ! \&$

Retnawati, H., Kartowagiran, B., Arlinwibowo, J., \& Sulistyaningsih, E. (2017). Why are the Mathematics National Examination Items Difficult and What is Teachers' Strategy to Overcome It? International Journal of Instruction, 10(3), 257-276.

https://doi.org/10.12973/iji.2017.10317a

Retnawati, H., Kartowagiran, B., Hadi, S., \& Hidayati, K. (2011). Identification of Student's Learning Difficulties on Mathematics and Science At Elementary School. Jurnal Kependidikan, 41(2), 162-174.

Sumantri, M. S., \& Puspita, R. (2014). Hubungan Antara Sikap Matematika Dan Lingkungan Belajar Terhadap Hasil Belajar Matematika Siswa Kelas V Sekolah Dasar. Jurnal Pendidikan Dasar Universitas Sebelas Maret, 2(2), 84-92.

Susila, I. M. O., Suardika, I. W. R., \& Suniasih, I. W. (2015). Model Pembelajaran Kooperatif Tipe NHT Berbantuan Media Konkret Berpengaruh Terhadap Hasil Belajar Matematika Siswa Kelas V SD Gugus VII Kecamatan Gianyar. MIMBAR PGSD Undiksha, 3(1). https:// doi.org/10.23887/jjpgsd.v3i1.5043

Widyasari, N. M. D., Meter, I. G., \& Negara, I. G. A. O. (2015). Analisis Kesulitan-Kesulitan 
Nur Fitriani Zainal, dkk

Belajar Matematika Siswa Kelas IV Dalam Implementasi Kurikulum 2013 Di SD Piloting Se-Kabupaten Gianyar. MIMBAR PGSD Undiksha, 3(1), 1-11. https:// ejournal.undiksha.ac.id/index.php/JJPGSD/article/view/5069

Wulansari, W., \& Kumaidi, K. (2015). Analisis Kesalahan Konsep Siswa Dalam Menyelesaikan Soal Ujian Nasional Matematika SD. Jurnal Ilmu Pendidikan Universitas Negeri Malang, 21(1), 97-105.

Y1lmazer, G., \& Masal, M. (2014). The Relationship between Secondary School Students' Arithmetic Performance and their Mathematical Literacy. Procedia - Social and Behavioral Sciences, 152, 619-623. https://doi.org/10.1016/j.sbspro.2014.09.253 